\title{
Parameters indicative of absorption and biological effect in new lead exposure: a prospective study
}

\author{
S. TOLA, S. HERNBERG, S. ASP, and J. NIKKANEN \\ Institute of Occupational Health, Helsinki, Finland
}

Tola, S., Hernberg, S., Asp, S., and Nikkanen, J. (1973). British Journal of Industrial Medicine, 30, 134-141. Parameters indicative of absorption and biological effect in new lead exposure: a prospective study. Determinations have been made of the blood and urinary lead concentrations ( $\mathrm{Pb}-\mathrm{B}, \mathrm{Pb}-\mathrm{U})$, haemoglobin concentrations $(\mathrm{Hb})$, packed blood cell volumes (Hcr), urinary $\delta$-aminolevulinic acid (ALA-U) and coproporphyrin concentrations (CP-U), as well as erythrocyte $\delta$-aminolevulinic acid dehydratase activities (ALA-D), in respect of 33 workers entering occupational lead exposure for the first time in their lives. In a follow-up study lasting from one to four months samples were taken before exposure began, initially at intervals of two days and subsequently at intervals of one to two weeks. Nine control subjects were studied for $\mathrm{Pb}-\mathrm{B}$ once, and for $\mathrm{Hb}, \mathrm{Hcr}$, and ALA-D weekly.

The $\mathrm{Pb}-\mathrm{B}$ rose and the ALA-D activity fell with no demonstrable time lag, while the latency periods of ALA-U, Pb-U, and CP-U were about two weeks. All of these laboratory tests reached a steady state during the follow-up.

ALA-D showed the highest correlation to $\mathrm{Pb}-\mathrm{B}$ and proved to be the most sensitive indicator of lead effect. Both CP-U and ALA-U were useful indicators of the effect of lead upon the organism, although a stepwise regression analysis, and their correlation coefficients with $\mathrm{Pb}-\mathrm{B}$, led to the conclusion that CP-U had better explaining power than ALA-U.

The mean $\mathrm{Hb}$ and $\mathrm{Hcr}$ values were significantly lower at the end of the observation period than at the beginning, providing an indication that anaemia begins to develop early in the course of lead absorption.

The relative value of various laboratory tests for the diagnosis and prevention of lead poisoning has aroused debate. The opinion today is that the concentration of lead in the blood $(\mathrm{Pb}-\mathrm{B})$ is superior to that in the urine $(\mathrm{Pb}-\mathrm{U})$ in the reflection of current exposure, while the amount of coproporphyrin (CP-U) or $\delta$-aminolevulinic acid (ALA-U) excreted into the urine best reflects the biological response (Gibson, MacKenzie, and Goldberg, 1968; Zielhuis, 1971; Haeger-Aronsen, 1971). These tests have gradually replaced the counting of stippled erythrocytes or reticulocytes in examinations of lead workers. However, another classical test, the haemoglobin value (Hb), is still commonly applied for both preventive and diagnostic purposes, although it is nonspecific and displays a poor correlation, if any, with other 'lead tests' (Williams, 1966).

No agreement has yet been reached on the relative merits of ALA-U and CP-U. Most authors recommend the former by reason of its greater sensitivity and specificity (Cramér and Selander, 1965; HaegerAronsen, 1971) but some prefer the latter (Williams, King, and Walford, 1969; Waldron, 1971). However, all of these opinions are based upon cross-sectional 
studies. Such studies do not consider the reproducibility of the tests, or their behaviour at an early stage in the course of exposure.

The finding that erythrocyte $\delta$-aminolevulinic acid dehydratase (ALA-D) is inhibited in lead exposure (Lichtman and Feldman, 1963) has recently led to the development of a new exposure test, which appears to possess some advantages over ALA-U and CP-U. First of all, the degree of inhibition bears a close correlation to the concomitant Pb-B (Hernberg et al., 1970; Millar et al., 1970; Haas et al., 1971; Haeger-Aronsen, Abdulla, and Fristedt, 1971; Weissberg, Lipschutz, and Oski, 1971). Secondly, the test appears to be practically specific for lead; the only other agent reported to induce a significant diminution in ALA-D activity is ethyl alcohol (Moore et al., 1971). Nevertheless, large doses are required, and the inhibition lasts for only a short time. Thirdly, ALA-D is far more sensitive than any other test (de Bruin and Hoolboom, 1967; de Bruin, 1968; Hernberg et al., 1969). The sensitivity of the ALA-D test renders it useful at low exposure levels such as those that occur in the general urban environment. On the other hand, this property may limit its use in industrial hygiene, as has been pointed out by some authors (de Bruin, 1968; Milić, Stanković, and Delić, 1970; Přerovská and Teisinger, 1970; Kehoe, 1971). Modification in the conditions of assay can, however, result in lowering of the sensitivity (Nikkanen, Hernberg, and Tola, 1972).

The lack of information from longitudinal, comparative studies on the most important parameters indicative of lead absorption and effect made it appear worth while to choose a new approach, a prospective study of new lead workers entering exposure for the first time in their lives. The results of this study are reported here.

\section{Material and methods}

\section{Exposure}

All the workers studied were employed in two storagebattery plants. In some departments the level of hygiene was poor. Air samplings made at the end of the observation period showed concentrations of up to $2 \mathrm{mg}, 3 \mathrm{mg}$, or even $4 \mathrm{mg}$ of lead per cubic metre of air in the work areas with the poorest hygiene. The use of personal protective equipment was common. The yearly incidence rate of clinical lead poisoning had been from 5 to $10 \%$. A detailed description of the exposure has been published elsewhere (Tola et al., 1971).

\section{Subjects}

Before employment began all the subjects were examined with a view to the exclusion of previous lead exposure and diseases that could affect interpretation of the data obtained. The first sampling (0-sample) was made in this connection. Five subjects had to be excluded by reason of previous lead exposure, but none because of disease. The number of subjects so selected was 33 (31 men and 2 women); their mean age was 25 (SD 7) years. Nine subjects were engaged in work with presumed heavy exposure (work at the lead oxide mill, paste mixing, pasting, and plate-drying), 19 in work with moderate exposure (casting, burning, and assembling), and five in work with presumed slight exposure (forming and repair). Nine healthy, unexposed men (mean age 24, SD 5, years) served as controls for the ALA-D, haemoglobin, and haematocrit determinations. These parameters were studied in accordance with the sampling scheme desscribed below. In the control group, $\mathrm{Pb}-\mathrm{B}$ was measured only at the first sampling, except in respect of one man whose $\mathrm{Pb}-\mathrm{B}$ was analysed weekly. ALA-U and CP-U were not measured for the controls.

\section{Design}

The original plan involved starting the sampling scheme before the beginning of exposure (day 0). Subsequent samples would then be taken on the second, fourth, and sixth days of exposure, followed by weekly samplings until the end of the third month, and two additional samplings at two-week intervals during the fourth and last month.

However, it proved impracticable to follow this scheme rigorously. First of all, weekends without exposure during the first six-day period disturbed the alternate-day schedule for most subjects. Secondly, on occasion minor ailments, necessitating a few days' sick leave, or public holidays meant longer intervals than had been planned. Thirdly, the drop-out of subjects reduced the cohort so that only 18 subjects remained for more than 70 days (maximum 134 days), nine were available for 30 to 70 days, and six for less than 30 days (minimum 10 days). In only one case was lack of cooperation the reason for drop-out. In 10 cases the worker transferred to other employment, and in six cases the follow-up had to be stopped when holidays interrupted exposure. In two subjects $\mathrm{Pb}-\mathrm{B}$ rapidly increased above the recommended levels, and the concentration of ALA-U and CP-U in the urine indicated incipient poisoning. Here we had torecommend immediate transfer to work without exposure. In three cases the first sample was not acquired until a few days after the beginning of exposure. Nevertheless, as there had been no previous history of exposure, they were accepted for follow-up.

\section{Laboratory methods}

Sampling was always performed between 2 p.m. and 4 p.m. To avoid errors arising from inaccurate collection of 24-hour urine samples, use was made of spot samples voided at the time of blood sampling. The afternoon has been recommended as the most suitable time for spot samples by Molyneux (1964). Blood samples were drawn from a cubital vein into heparinized test tubes, which had been rendered lead-free by being washed with $10 \%$ nitric acid and redistilled water. This method of washing was used also for the urine flasks.

$\mathrm{Pb}-\mathrm{B}$ and $\mathrm{Pb}-\mathrm{U}$ were determined from duplicate samples by means of atomic absorption spectrophotometry (Perkin-Elmer 303), according to the method of Hessel (1968). The method error from duplicate measurements of $\mathrm{Pb}-\mathrm{B}$ was $\pm 2 \cdot 1 \mu \mathrm{g} / 100 \mathrm{ml}$ and of $\mathrm{Pb}-\mathrm{U} \pm 3 \cdot 2$ $\mu \mathrm{g} / 1$.

Erythrocyte ALA-D activity was estimated according 
to our modification (Nikkanen et al., 1972) of the method of Bonsignore, Calissano, and Cartasegna (1965). All the analyses were begun within three hours of sampling. The results are expressed as $\mu \mathrm{mol}$ porphobilinogen (PBG) formed during one hour's incubation at $37^{\circ} \mathrm{C}$, per litre of packed red blood cells, as estimated from the previously determined haematocrit value, or $\mu \mathrm{mol}$ PBG per hour per 1 RBC.

Blood haemoglobin $(\mathrm{Hb})$ was determined by the standard method after conversion to cyanmethaemoglobin. The haematocrit value (Hcr) was measured with an Adams Autocrit centrifuge model CT 2900; duplicate samples were spun for 4 minutes at $15.500 \mathrm{~g}$.

ALA-U was determined by the method of Grabecki, Haduch, and Urbanowicz (1967).

CP was extracted from the urine by Askerold's (1951) method. Coproporphyrinogen was oxidized (Schwartz, Zieve, and Watson, 1951), and the calculations were made by application of the formula given by Rimington and Sveinsson (1950) and amended by With (1955).

The $\mathrm{CP}-\mathrm{U}$ and $\mathrm{Pb}-\mathrm{U}$ values were corrected to a specific gravity of 1.024 , according to Levine and Fahy (1945). The corrected values were used for comparison with other tests as the correlations with $\mathrm{Pb}-\mathrm{B}$ were superior to those without correction (CP-U, $\mathrm{r}=0.54$ and $0.48 ; \mathrm{Pb}-\mathrm{U}$, $\mathrm{r}=0.58$ and 0.49 ).

No correction was applied for ALA-U, as Cramér and Selander (1967) and Haeger-Aronsen (1970) have demonstrated that this is unnecessary.

\section{Statistical methods}

The group levels of Pb-B, ALA-D, ALA-U, CP-U, and $\mathrm{Pb}-\mathrm{U}$ were determined by calculation of the means and standard deviations in different time groups at the beginning of the exposure with intervals of five days, and later at intervals of 10 days. The distribution of these laboratory values was skewed, and accordingly logarithmic transformation was used. In the final phase, in order to eliminate some non-essential zigzagging from the curves, the means and mean \pm standard deviations were smoothed by the moving average technique. The smoothed value of a group was calculated by summing the value of the previous group, the value of the group itself, and the value of the following group. The value of the group itself was weighted by 2 and the values of the neighbouring groups by 1 ; the weighted sum was divided by 4 . All the tests and correlation coefficients, however, have been calculated with the unsmoothed values. For $\mathrm{Hb}$ and Hor values, simple arithmetic means and standard deviations could be employed.

To study the intercorrelations between Pb-B, ALA-D, ALA-U, CP-U, and $\mathrm{Hb}$, within-subject correlations were calculated separately for each subject. ALA-D was transformed logarithmically.

The correlation coefficients between these tests for all the subjects were also calculated by consideration of all the values of each subject at different points in the calculations. In view of the possibility of curvilinear relationships between $\mathrm{Pb}-\mathrm{B}$ and ALA-U (Selander and Cramér, 1970; Müller and Holzapfel, 1971), and Pb-B and CP-U (Zielhuis, 1971), logarithmic values for ALA-U and CF-U were also employed in these calculations.

The possibility of improvement in the predictive capacity of the other tests for $\mathrm{Pb}-\mathrm{B}$, by combination of information derived from several laboratory tests, was examined by forward stepwise regression analysis (Draper and Smith, 1966). All the observed values of each laboratory test were given to the computer, and the fact that they were successive readings of the same subjects was not taken into account in the analysis. $\mathrm{Pb}-\mathrm{B}$ was the dependent variable, while exposure time, ALA-D, InALA-D, ALA-U, CP-U, and Pb-U, their squares, and the products of time and these test values, were independent variables. The following equations were derived:

1. If time was included in the analysis as an obligatory independent variable

$$
\begin{aligned}
& \text { Model: } y=a+b_{1} x_{1}+b_{2} x_{1}^{2}+b_{3} x_{2}+b_{4} x_{2}^{2} \\
& +b_{5} x^{2} \\
& \text { where: } y=\text { Pb-B } \\
& x_{1}=\text { time } \\
& x_{2}=\text { CP-U } \\
& x_{3}=\text { ALA-D } \\
& x_{4}=\text { InALA-D } \\
& \mathrm{R}=0.784 \\
& \text { residual deviation }=9 \cdot 3
\end{aligned}
$$

$\begin{array}{rr}\text { Coefficients: } a=57 \cdot 441 & t \\ b_{1}=0 \cdot 451 & 5 \cdot 62 \\ b_{2}=-0.00345 & 5 \cdot 24 \\ b_{3}=0 \cdot 0164 & 4 \cdot 35 \\ b_{4}=-0 \cdot 00000217 & 2 \cdot 78 \\ b_{5}=0 \cdot 0000167 & 2 \cdot 03 \\ b_{6}=-1 \cdot 0196 & 6 \cdot 10\end{array}$

2. If time was not one of the independent variables in the analysis

$$
\begin{aligned}
& \text { Model: } y=a+b_{1} x_{1}+b_{2} x_{2}+b_{3} x_{2}{ }^{2}+b_{4} x_{3}{ }^{2} \\
& \text { where: } y=\text { Pb-B } \\
& x_{1}=\text { CP-U } \\
& x_{2}=\text { Pb-U } \\
& x_{3}=1 \text { nALA-D } \\
& \begin{array}{rl}
\mathrm{R}=0.778 & \\
\text { residual deviation }=9.5 & t \\
\text { Coefficients: } a=46.203 & 3 \cdot 30 \\
b_{1}=0.00567 & 5 \cdot 57 \\
b_{2}=0.1564 & 4.60 \\
b_{3}=-0.000221 & 4.67 \\
b_{4}=-0.6308 &
\end{array}
\end{aligned}
$$

\section{Results}

All the parameters studied displayed the expected behaviour after the beginning of exposure, i.e., ALA-D activity fell and $\mathrm{Pb}-\mathrm{B}, \mathrm{Pb}-\mathrm{U}, \mathrm{CP}-\mathrm{U}$, and ALA-U rose (Figs. 1 and 2). However, some interesting differences were evident: $\mathrm{Pb}-\mathrm{B}$ and ALA-D reacted after only a few days of exposure. The values attained a steady state after some two months, ALA-D a little sooner than $\mathrm{Pb}-\mathrm{B}$. The rapid reaction of ALA-D upon increased lead absorption confirms that this parameter is the most sensitive one. In fact, even after five days ALA-D activity had declined to less than one half of its original value. The stability of the corresponding values of the controls (Fig. 1) 

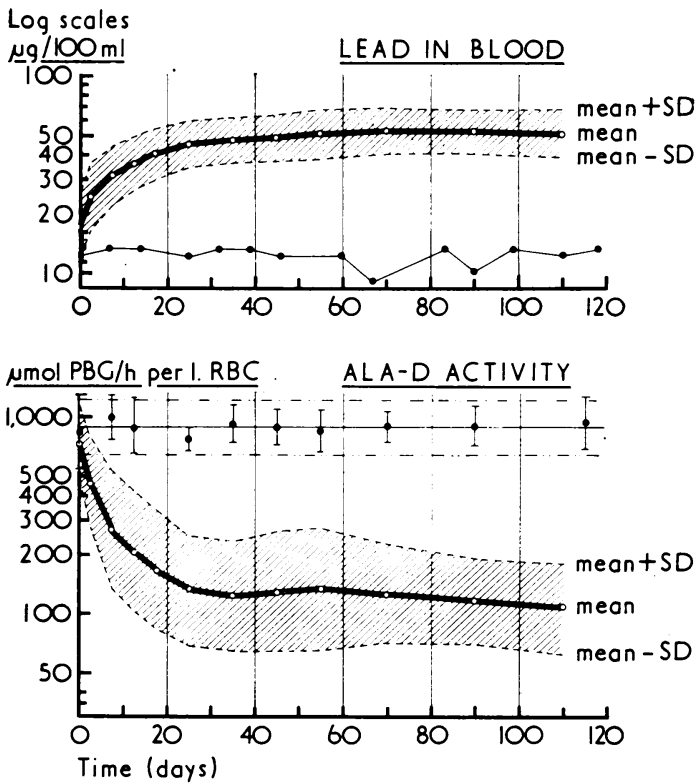

FIG. 1. Smoothed average blood lead concentrations and ALA-D activities plotted against time in semilogarithmic scales. ALA-D activities in the control group are presented together with the ALA-D curve of the exposed subjects, and the blood lead concentrations in one control subject are presented together with the blood lead curve of the exposed subjects. Shadowed area indicates the standard deviation.

demonstrates that this is not attributable to methodological errors.

In contrast to $\mathrm{Pb}-\mathrm{B}$ and $\mathrm{ALA}-\mathrm{D}$, it was about two weeks before a measurable increase became apparent in the excretion of ALA-U and CP-U (Fig. 2). By that time, the corresponding $\mathrm{Pb}-\mathrm{B}$ had risen to over $40 \mu \mathrm{g} / 100 \mathrm{ml}$. Pb-U followed $\mathrm{Pb}-\mathrm{B}$ more closely. Figure 3 illustrates the effect of the rising $\mathrm{Pb}-\mathrm{B}$ upon ALA-D, Pb-U, CP-U, and ALA-U.

It is apparent from Table 1 that a slight fall occurred in the mean haemoglobin value in the exposed group. The mean of the individual differences between the first and last values differed statistically significantly from zero $(t=4.94, \mathrm{P}<0 \cdot 001)$. No such difference was observed in the control group. Moreover, the haematocrit fell significantly towards the end of the follow-up $(t=6.86, \quad \mathrm{P}<0.001)$. However, also in the control group a slight difference was seen between the first and the last values $(t=2 \cdot 46, \mathrm{P}<0 \cdot 05)$. More detailed examination of the serial measurements showed a time trend in the exposed group (Table 1) but only random variation in the control group. Thus the fall in the haematocrit value in the former group was probably a true effect; however, evaluation is rendered difficult by the

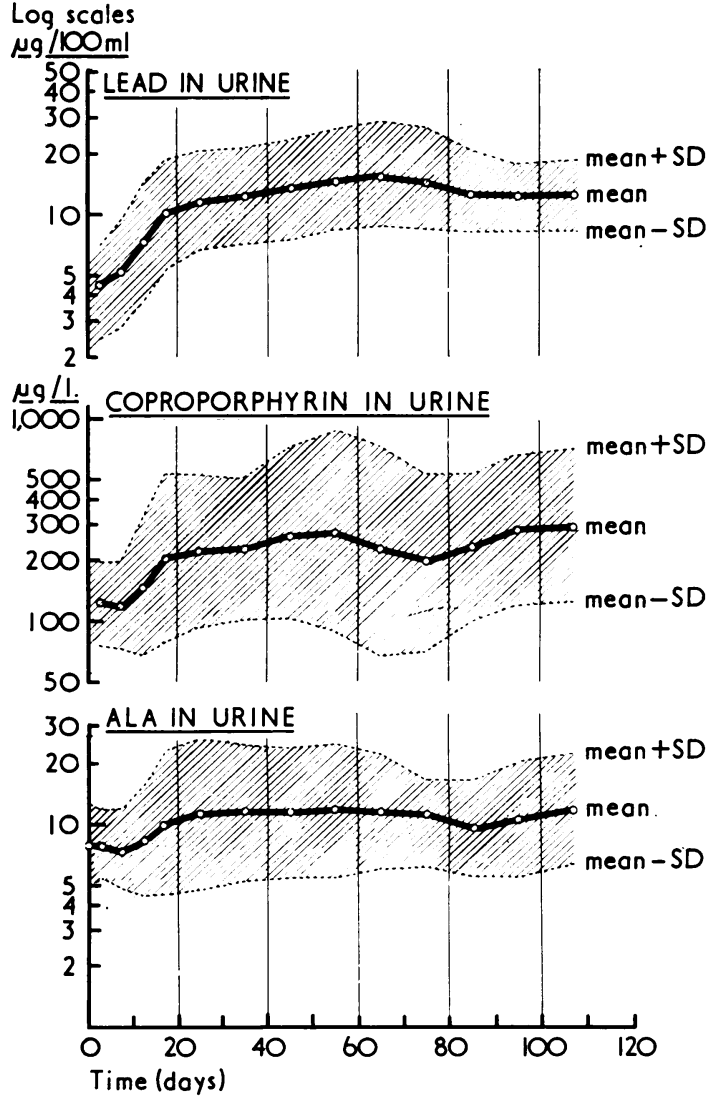

FIG. 2. Smoothed average lead, coproporphyrin, and ALA concentrations in urine plotted against time in a semilogarithmic scale. Shadowed area indicates the standard deviation.

within-subject variation of the haematocrit being even more pronounced than the supposed effect.

Whereas the sensitivity of the various tests can be studied by direct observation of the results, investigation of their reliability calls for more complicated mathematical operations. Reliability is here defined as the most accurate reflection of the intensity of exposure, as expressed by $\mathrm{Pb}-\mathrm{B}$, which contains a requirement for a variation as small as possible. The operating procedure involved calculation of the correlations between $\mathrm{Pb}-\mathrm{B}$ and the other parameters, both within the same subject and within the pooled material. In addition, a forward stepwise regression analysis was made for selection of the best combination of tests to predict $\mathrm{Pb}-\mathrm{B}$. As this was done principally for practical purposes, the logarithmic values of ALA-U and CP-U were not included (Zielhuis, 1971). It needs to be stressed here that these statistical operations 


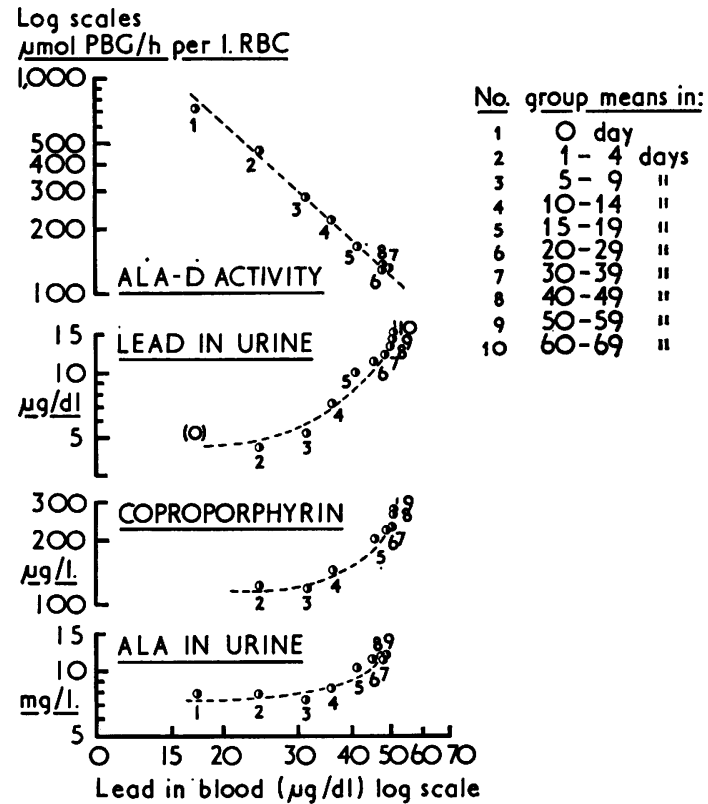

FIG. 3. Smoothed averages of ALA-D activities, lead, coproporphyrin, and ALA concentrations in urine within each time group plotted against blood lead concentration in logarithmic scales, showing the relative different behaviour of these tests with a rise in blood lead.

alone should not be used for medical conclusions as some of the parameters measure absorption and other responses.

Of all the relationships tested, the natural logarithm of ALA-D displayed the highest correlation with $\mathrm{Pb}$-B. Its within-subject correlation coefficients were all markedly negative and had a fairly narrow range $(-0.99$ to -0.59$)$. The corresponding correlations for $\mathrm{Pb}-\mathrm{U}, \mathrm{CP}-\mathrm{U}, \mathrm{ALA}-\mathrm{U}$, and $\mathrm{Hb}$ were less stable, and their within-subject correlations varied from strongly negative to strongly positive.

Correlations calculated from the pooled whole material conform with those obtained within single subjects; 1nALA-D had the highest, and $\mathrm{Hb}$ the lowest, correlation with Pb-B (Tables 2 to 8). ALA-D and InALA-D also displayed fairly good correlation with the other tests; their correlation coefficients were of the same magnitude as those of $\mathrm{Pb}-\mathrm{B}$ (Tables 2 to 8 ). In regard to the urine tests, $\mathrm{Pb}-\mathrm{U}$ had the highest correlation with both $\mathrm{Pb}-\mathrm{B}$ and ALA-D, while ALA-U had the lowest. The logarithmic transformation of CP-U and ALA-U slightly improved the correlation, 1nCP-U having the same correlation coefficient to $\mathrm{Pb}-\mathrm{B}$ as $\mathrm{Pb}-\mathrm{U}$. Although the correlation coefficient of 1nALA-U to $\mathrm{Pb}-\mathrm{B}$ was superior to that without logarithmic transformation, ALA-U still remained the poorest of the urine tests studied (Table 2). All the urine tests

TABLE 2

Correlation Coefficients between Pb-B and OTHER Tests

\begin{tabular}{lr}
\hline Test & \multicolumn{1}{c}{$r$} \\
\hline Pb-U & 0.58 \\
ALA-D & -0.60 \\
1nALA-D & -0.70 \\
ALA-U & 0.38 \\
1nALA-U & 0.46 \\
CP-U & 0.54 \\
1nCP-U & 0.58 \\
Hb & -0.13 \\
\hline
\end{tabular}

TABLE 1

Arithmetic Means of Hb and Hcr in Different Time Periods

\begin{tabular}{|c|c|c|c|c|c|c|}
\hline \multirow{2}{*}{$\begin{array}{c}\text { Time } \\
\text { (days) }\end{array}$} & \multicolumn{3}{|c|}{ Haemoglobin $(\mathrm{g} / 100 \mathrm{ml})$} & \multicolumn{3}{|c|}{ Haematocrit \% } \\
\hline & $\mathbf{n}$ & Mean & $S D$ & $\mathbf{n}$ & Mean & $S D$ \\
\hline $\begin{array}{c}0 \\
1-4 \\
5-9 \\
10-14 \\
15-19 \\
20-29 \\
30-39 \\
40-49 \\
50-59 \\
60-69 \\
70-79 \\
80-99 \\
100-\end{array}$ & $\begin{array}{l}30 \\
25 \\
20 \\
23 \\
27 \\
29 \\
26 \\
25 \\
20 \\
17 \\
10 \\
14 \\
14\end{array}$ & $\begin{array}{l}14 \cdot 4 \\
14 \cdot 1 \\
14 \cdot 3 \\
14 \cdot 0 \\
13 \cdot 8 \\
14 \cdot 0 \\
13 \cdot 9 \\
13 \cdot 9 \\
13 \cdot 7 \\
13 \cdot 7 \\
137 \\
13 \cdot 9 \\
13 \cdot 4\end{array}$ & $\begin{array}{l}1.0 \\
1.1 \\
0.9 \\
1.0 \\
1.0 \\
1.0 \\
1.1 \\
0.9 \\
0.8 \\
07 \\
1.0 \\
0.9 \\
0.7\end{array}$ & $\begin{array}{l}30 \\
25 \\
20 \\
23 \\
27 \\
29 \\
26 \\
25 \\
20 \\
17 \\
10 \\
14 \\
14\end{array}$ & $\begin{array}{l}46 \\
44 \\
44 \\
44 \\
43 \\
43 \\
43 \\
43 \\
43 \\
44 \\
44 \\
44 \\
43\end{array}$ & $\begin{array}{l}3 \\
3 \\
2 \\
3 \\
3 \\
2 \\
2 \\
3 \\
2 \\
2 \\
2 \\
2 \\
2 \\
2 \\
2\end{array}$ \\
\hline
\end{tabular}


TABLE 3

Correlation Coefficients between ALA-D AND OTHER TESTS

\begin{tabular}{ll}
\hline Test & $r$ \\
\hline Pb-B & $-0 \cdot 60$ \\
Pb-U & -0.46 \\
ALA-U & $-0 \cdot 23$ \\
CP-U & -0.31 \\
Hb & $0 \cdot 16$ \\
\hline
\end{tabular}

TABLE 4

Correlation CoefFicients Between 1nALA-D AND OTHER TESTS

\begin{tabular}{ll}
\hline Test & $r$ \\
\hline Pb-B & -0.70 \\
Pb-U & -0.57 \\
ALA-U & -0.36 \\
CP-U & -0.51 \\
Hb & 0.22 \\
\hline
\end{tabular}

TABLE 5

Correlation Coefficients between Pb-U and OTHER TESTS

\begin{tabular}{lr}
\hline Test & \multicolumn{1}{c}{$r$} \\
\hline Pb-B & 0.58 \\
ALA-D & -0.46 \\
1nALA-D & -0.57 \\
ALA-U & 0.39 \\
CP-U & 0.48 \\
Hb & -0.17 \\
\hline
\end{tabular}

displayed a fairly high mutual correlation (Tables 5 to 7). However, exact levels of statistical significance for these coefficients cannot be determined since the calculations have been performed on data involving successive readings on the same subject.

The forward stepwise regression analysis did not select ALA-U at any of its steps. If time was an obligate variate in the analysis, InALA-D ${ }^{2}$, time, and its square were the most powerful variables in the model. CP-U was next in order. CP- $\mathrm{U}^{2}$ and ALA-D ${ }^{2}$ improved the regression, although statistically they were not so significant as time and InALA-D ${ }^{2}$.

If time was omitted from the analysis, $\mathrm{Pb}-\mathrm{U}$ had the greatest explaining power; 1nALA-D ${ }^{2}$ and $\mathrm{Pb}-\mathrm{U}^{2}$ were next in order, and $\mathrm{CP}-\mathrm{U}$ was weakest, while ALA-U did not improve the correlation at all. The regression was about as significant as in the model which included time $(R=0.778$ without time in the model, and $R=0.784$ with time as an obligate
TABLE 6

Correlation Coefficients between AlA-U AND OTHER TESTS

\begin{tabular}{lr}
\hline Test & \multicolumn{1}{c}{$r$} \\
\hline Pb-B & $0 \cdot 38$ \\
Pb-U & $0 \cdot 39$ \\
ALA-D & $-0 \cdot 23$ \\
1nALA-D & -0.36 \\
CP-U & 0.48 \\
Hb & -0.14 \\
\hline
\end{tabular}

TABLE 7

Correlation Coefficients between CP-U AND OTHER Tests

\begin{tabular}{lr}
\hline Test & \multicolumn{1}{c}{$r$} \\
\hline Pb-B & $0 \cdot 54$ \\
Pb-U & $0 \cdot 48$ \\
ALA-D & $-0 \cdot 31$ \\
InALA-D & $-0 \cdot 51$ \\
ALA-U & $0 \cdot 48$ \\
Hb & $-0 \cdot 22$ \\
\hline
\end{tabular}

TABLE 8

Correlation Coefficients between Hb and OTHER TESTS

\begin{tabular}{lr}
\hline Test & \multicolumn{1}{c}{$r$} \\
\hline Pb-B & $-0 \cdot 13$ \\
Pb-U & $-0 \cdot 17$ \\
ALA-D & $0 \cdot 16$ \\
1nALA-D & $0 \cdot 22$ \\
ALA-U & $-0 \cdot 14$ \\
CP-U & $-0 \cdot 22$ \\
\hline
\end{tabular}

variate), which indicates that if $\mathrm{Pb}-\mathrm{B}$ is to be predicted from the above parameters, it is unnecessary to know the duration of exposure.

By way of summary, it may be said that all the statistical procedures employed selected ALA-D from the parameters indicating response as being the most reliable reflector of $\mathrm{Pb}-\mathrm{B}$. CP-U came second, followed by ALA-U and $\mathrm{Hb}$.

\section{Discussion}

A prospective design adds a new dimension to the study of the relative merits, such as sensitivity and reliability, of the various parameters applied to the evaluation of lead absorption and effect. In this respect, the first weeks of exposure are of particular interest, since the time sequence of the reaction of the different tests during this period is a good indicator of their relative sensitivity. Moreover, following the subjects for some time by periodic sampling provides 
a fairly good estimate of the relative reliability of the tests.

If $\mathrm{Pb}-\mathrm{B}$ is considered to be the best criterion of absorption (Williams et al., 1968 and 1969; Holmqvist, 1969), all the statistical procedures employed clearly showed that the ALA-D assay was the most reliable test of lead effect. CP-U came second, followed by ALA-U and $\mathrm{Hb}$.

$\mathrm{Pb}-\mathrm{U}$ reflected $\mathrm{Pb}-\mathrm{B}$ fairly well, as was to be expected from the previous cross-sectional studies (Williams et al., 1968 and 1969). $\mathrm{Pb}-\mathrm{U}$ can thus be regarded as a useful test of lead absorption also at the beginning of exposure. However, it is not so suitable as $\mathrm{Pb}-\mathrm{B}$, as numerous factors other than the degree of lead absorption alone influence the urinary excretion of lead, such as renal function, fluid intake, and specific gravity of the urine (Levine and Fahy, 1945; Molyneux, 1964; Malcolm, 1965; Ellis, 1966).

As was pointed out above in the description of the results, these statistical operations alone are not necessarily of practical medical significance. Aspects such as the sampling procedures, the effect of storage and so on are certainly of greater importance than slight statistical differences. Furthermore, the high degree of sensitivity of ALA-D may be a disadvantage, as has been pointed out by de Bruin (1968), Přerovská and Teisinger (1970), and Kehoe (1971). The favourable conclusions drawn here in regard to ALA-D may be attributable in part to the relative lowness of the $\mathrm{Pb}-\mathrm{B}$ values; this naturally limits the impact of the observations made in this work under conditions of moderate or slight exposure.

The close relationship between $\mathrm{Pb}-\mathrm{B}$ and the depression of ALA-D activity has already been demonstrated on several occasions and does not call for further comment (Hernberg et al., 1970 and 1972; Haas et al., 1971; Haeger-Aronsen et al., 1971). In this context it is interesting to note that the depression of ALA-D activity occurred with no demonstrable time lag. In contrast, the first effect upon CP-U and ALA-U was not evident until the $\mathrm{Pb}-\mathrm{B}$ exceeded about $40 \mu \mathrm{g} / 100 \mathrm{ml}$. These results confirm beyond doubt that ALA-D is a more sensitive indicator of lead effect than CP-U or ALA-U, and that the last-mentioned are almost equally sensitive (Fig. 3; Table 2). On a comparison of ALA-U and CP-U the present results favour CP-U. However, the method applied here for the determination of ALA-U (Grabecki et al., 1967) which is less specific than the original method (Mauzerall and Granick, 1956), has probably incapacitated ALA-U somewhat.

The anaemia of lead poisoning is accepted as one of its main features (Griggs, 1964). The use of $\mathrm{Hb}$ determinations for evaluation of the early stages of lead poisoning in industrial hygiene has been a matter of some controversy. Malcolm (1965) does not consider the appearance of anaemia as being an early sign, and Williams (1966) was unable to find any change in the $\mathrm{Hb}$ until the $\mathrm{Pb}-\mathrm{B}$ exceeded 110 $\mu \mathrm{g} / 100 \mathrm{ml}$. Against this, Müller and Holzapfel (1969) are of the opinion that a fall in $\mathrm{Hb}$ precedes symptoms of lead poisoning in such a way that this test would be useful for preventive purposes.

The results obtained in this investigation (Table 1) indicate that a fall in $\mathrm{Hb}$ is indeed an early lead effect, becoming evident in groups of workers within a period of two to three months. It is probable that most of the difficulties encountered in demonstrating the effects of lead upon the haemoglobin values originate in the relatively wide range of normal variation. An $\mathrm{Hb}$ value of $14 \mathrm{~g} / 100 \mathrm{ml}$ in one individual is as normal as that of $16 \mathrm{~g} / 100 \mathrm{ml}$ in another. The results obtained consequently support the opinion of Holmqvist (1962) and Zielhuis (1971), that the essential point, if $\mathrm{Hb}$ estimations are used for preventive purposes and not for the diagnosis of lead poisoning, is observation of the differences in serial estimations. A decreasing $\mathrm{Hb}$ value is an important indication of lead effect, provided that other causes of developing anaemia can be excluded.

Our thanks are due to Miss Sinikka Valkonen for surveillance of the blood and urine analyses and the urinary coproporphyrin analyses.

We wish to thank the management of the electric storage-battery factories for allowing us to carry out the study and, in particular, the workers for their understanding attitude and patience with repeated samplings.

This study has been aided by grants to S.H. from the 'Finska Läkaresällskapets Fonder' and from the Medical Research Council of Finland.

\section{References}

Askevold, R. (1951). Routine analysis of porphyrines in urine. Scandinavian Journal of Clinical and Laboratory Investigation, 3, 318-319.

Bonsignore, D., Calissano, P., and Cartasegna, C. (1965). Un semplice metodo per la determinazione della deltaamino-levulinico-deidratasi nel sangue. Comportamento dell' enzima nell' intossicazione saturnina. Medicina del Lavoro, 56, 199-205.

de Bruin, A. (1968). Effect of lead exposure on the level of delta-aminolevulinic-dehydratase activity. Medicina del Lavoro, 59, 411-418.

, and Hoolboom, H. (1967). Early signs of lead-exposure. A comparative study of laboratory tests. British Journal of Industrial Medicine, 24, 203-212.

Cramér, K., and Selander, S. (1965). Studies in lead poisoning. Comparison between different laboratory tests. British Journal of Industrial Medicine, 22, 311-314.

- and - (1967). Control of lead workers by determination of urinary delta-aminolaevulinic acid. British Journal of Industrial Medicine, 24, 283-288.

Draper, N. R., and Smith, H. (1966). Applied Regression Analysis, 1st ed., pp. 171-172. John Wiley, New York.

Ellis, R. W. (1966). Urinary screening tests to detect excessive lead absorption. British Journal of Industrial Medicine, 23, 263-275.

Gibson, S. L. M., MacKenzie, J. C., and Goldberg, A. (1968). The diagnosis of industrial lead poisoning. British Journal of Industrial Medicine, 25, 40-51. 
Grabecki, J., Haduch, T., and Urbanowicz, H. (1967). Die einfachen Bestimmungsmethoden der Delta-Aminolävulinsäure im Harn. Internationales Archiv für Gewerbepathologie und Gewerbehygiene, 23, 226-240.

Griggs, R. C. (1964). Lead poisoning: Hematologic aspects. Progress in Hematology, 4, 117-137.

Haas, T., Mache, K., Schaller, K. H., and Valentin, H. (1971). Die Delta-Aminolävulinsäure-Dehydratase als wertvoller biochemischer Parameter bei der Überwachung von Bleiarbeitern. Arbeitsmedizin, Sozialmedizin, Arbeitshygiene, 6, 303-305.

Haeger-Aronsen, B. (1970). Evaluation of two methods for measuring $\delta$-aminolaevulinic acid in urine. Scandinavian Journal of Clinical and Laboratory Investigation, 25, 19-23.

- (1971). An assessment of the laboratory tests used to monitor the exposure of lead workers. British Journal of Industrial Medicine, 28, 52-58.

- Abdulla, M., and Fristedt, B. I. (1971). Effect of lead on $\delta$-aminolevulinic acid dehydrase activity in red blood cells. Archives of Environmental Health, 23, 440-445.

Hernberg, S., Lilius, H., Mellin, G., and Nikkanen, J. (1969). Lead exposure of workers in printing shops. WorkEnvironment-Health (Helsinki), 6, 5-8.

- Nikkanen, J., Mellin, G., and Lilius, H. (1970). $\delta$-aminolevulinic acid dehydrase as a measure of lead exposure. Archives of Environmental Health, 21, 140-145. , Tola, S., Nikkanen, J., and Valkonen, S. (1972). Erythrocyte $\delta$-aminolevulinic acid dehydratase in new lead exposure. A longitudinal study. Archives of Environmental Health, 25, 109-113.

Hessel, D. W. (1968). A simple and rapid quantitative determination of lead in blood. Atomic Absorption Newsletters, 7, 55-56.

Holmqvist, I. (1962). Laboratorieundersökningar vid periodisk besiktning av blyarbetare. Nordisk Medicin, 67, 46-51.

- (1969). Blood lead determinations in control of exposed workers. Arhiv Za Higijenu Toksikologiju, 20, Supplement to No. 4, 43-47.

Kehoe, R. A. (1971). Standards for the prevention of occupational lead poisoning. Archives of Environmental Health, 23, 245-248.

Levine, L., and Fahy, J. P. (1945). Evaluation of urinary lead determinations. I. The significance of the specific gravity. Journal of Industrial Hygiene, 27, 217-223.

Lichtman, H. C., and Feldman, F. (1963). In vitro pyrrole and porphyrin synthesis in lead poisoning and iron deficiency. Journal of Clinical Investigation, 42, 830-839.

Malcolm, D. (1965). Industrial control of personnel. Annals of Occupational Hygiene, 8, 35-42.

Mauzerall, D., and Granick, S. (1956). The occurrence and determination of $\delta$-aminolevulinic acid and porphobilinogen in urine. Journal of Biological Chemistry, 219, 435446.

Milić, S., Stanković, M., and Delić, V. (1970). Effect of low lead exposure on the level of delta-aminolevulinic acid dehydratase activity. Arhiv Za Higijenu I Toksikologiju, 21, 241-246.

Millar, J. A., Battistini, V., Cumming, R. L. C., Carswell, F., and Goldberg, A. (1970). Lead and $\delta$-aminolaevulinic acid dehydratase levels in mentally retarded children and in lead-poisoned suckling rats. Lancet, 2, 695-698.

Molyneux, M. K. B. (1964). Use of single urine samples for the assessment of lead absorption. British Journal of Industrial Medicine, 21, 203-209.
Moore, M. R., Beattie, A. D., Thompson, G. G., and Goldberg, A. (1971). Depression of $\delta$-aminolaevulic acid dehydrase activity by ethanol in man and rat. Clinical Science, 40, 81-88.

Müller, W., and Holzapfel, G. (1969). Zur Frage der Wertigkeit verschiedener üblicher Laboruntersuchungsmethoden bei der Bleiprophylaxe. Zeitschrift für die gesamte Hygiene und ihre Grenzgebiete, 15, 496-501.

— and - (1971). Über die Beziehung zwischen DeltaAminolävulinsäure-Ausscheidung im Harn und Blutbleispiegel bei Arbeitern mit unterschiedlicher Bleiexposition. Internationales Archiv für Arbeitsmedizin, 27, 331-337.

Nikkanen, J., Hernberg, S., and Tola, S. (1972). Modifications of the $\delta$-aminolevulinic acid dehydratase test and their significance for assessing different intensities of lead exposure. Work-Environment-Health, 9, 46-52.

Přerovská, I., and Teisinger, J. (1970). Excretion of lead and its biological activity several years after termination of exposure. British Journal of Industrial Medicine, 27, 352355.

Rimington, C., and Sveinsson, S. L. (1950). The spectrophotometric determination of uroporphyrin. Scandinavian Journal of Clinical and Laboratory Investigation, 2, 209-216.

Schwartz, S., Zieve, L., and Watson, C. J. (1951). An improved method for the determination of urinary coproporphyrin and an evaluation of factors influencing the analysis. Journal of Laboratory and Clinical Medicine, 37, 843-859.

Selander, S., and Cramér, K. (1970). Interrelationships between lead in blood, lead in urine and ALA in urine during lead work. British Journal of Industrial Medicine, 27, 28-39.

Tola, S., Hernberg, S., Nikkanen, J., and Valkonen, S. (1971). Occupational lead exposure in Finland: I. Electric storage battery manufacturing and repair. WorkEnvironment-Health, 8, 81-85.

Waldron, H. A. (1971). Correlation between some parameters of lead absorption and lead intoxication. British Journal of Industrial Medicine, 28, 195-199.

Weissberg, J. B., Lipschutz, F., and Oski, F. A. (1971). $\delta$-Aminolevulinic acid dehydratase activity in circulating blood cells. A sensitive laboratory test for the detection of childhood lead poisoning. New England Journal of Medicine, 284, 565-569.

Williams, M. K. (1966). Blood lead and haemoglobin in lead absorption. British Journal of Industrial Medicine, 23, 105-111.

-, King, E., and Walford, J. (1968). Method for estimating objectively the comparative merits of biological tests of lead exposure. British Medical Journal, 1, 618-621.

- - - and - (1969). An investigation of lead absorption in an electric accumulator factory with the use of personal samplers. British Journal of Industrial Medicine, 26, 202-216.

With, T. K. (1955). Porphyrin concentration from ultraviolet extinction. A note on the calculation. Scandinavian Journal of Clinical and Laboratory Investigation, 7, 193-194.

Zielhuis, R. L. (1971). Interrelationship of biochemical responses to the absorption of inorganic lead. Archives of Environmental Health, 23, 299-311.

Received for publication July 24, 1972.

Accepted for publication October 18, 1972. 